\title{
Docētāju profesionālās pilnveides pieredze Latvijas Universitātes Rakstos
}

\section{Development of Academic Staff Professional Development in University of Latvia Scientific Papers}

\author{
Sanita Baranova \\ Latvijas Universitāte \\ Pedagoǵijas, psiholoǵijas un mākslas fakultāte \\ E-pasts: sanita.baranova@lu.Iv
}

Ilona Vēliṇa-Švilpe

Latvijas Universitātes Bibliotēka

E-pasts: ilona.velina-svilpe@lu.lv

Universitātes darbībā klasiskā un reizē mūsdienīgā studiju un pētniecības vienotības principa ievērošana rosina docētājus ne tikai izstrādāt publikācijas par veiktajiem zinātniskajiem pètījumiem zinātṇu nozarēs, bet arī raksturot un zinātniski pamatot savu kā augstākās izglīiỉbas pedagoga darbību. Raksta mērḳis - sniegt ieskatu docētāju profesionālās pilnveides pieredzes pedagogiskās darbības jomas atspoguḷojumā LU Rakstos, padziḷināti analizējot saturu LU Rakstu sērijās "Izglīîibas kvalitāte un vadība", "Izglìtības zinātnes un pedagogiija mūsdienu pasaulē", "Pedagoǵija", "Pedagoǵija un skolotāju izglīiība" un "Izglitības vadība", kas izdotas no 2000. līdz 2015. gadam. Tika noteikti vairāki publikāciju tematiskie virzieni, kādos raksturota un izvērtēta docētāju pedagogiskā pieredze un profesionālā pilnveide: aktualitātes un tendences augstākajā izglīîibā, augstākās izglìtības vēsturiskā attīstîba, studiju programmu un studiju kursu izstrāde un aktualizācija, studentu mācīšanās aspekti, docētāju profesionālās pilnveides aktualitāte, docētāju pedagogiskā darba pieredzes raksturojums un izvērtējums, docētāja (raksta autora) pedagoǵiskā darba pieredzes zinātniski pamatota analīze.

Atslēgvārdi: docētāji, profesionālā pilnveide, pieredze.

\section{Summary}

Compliance of university's work with the classical and at the same time modern principle of unity between studies and research encourages academic staff to dedicate publications not only to the research implemented in the fields of science but also to describe and scientifically substantiate their work performed as the university academic staff. The aim of the article is to explore how the professional development experience of the university lecturers is reflected in the scientific papers on higher education and 
tertiary pedagogy published in the following volumes of the University of Latvia Scientific Papers: "The Quality and Management of Education", "Educational Sciences and Pedagogy in the Changing World", "Pedagogy", "Pedagogy and Teacher Education", and "Education Management" published from 2000 to 2015. Several thematic directions of publications were defined according to description and evaluation of pedagogical experience and professional development of academic staff: topicalities and trends in higher education, historical development of higher education, development and updating of study programmes and courses, aspects of student learning, current issues of academic staff professional development, characterization and evaluation of lecturers' experience in pedagogical work, scientifical analysis of pedagogical work experience of the lecturer (author of the article).

Keywords: university academic staff, professional development, experience.

\section{levads}

2015. gada 22. septembrī Latvijas Universitātes (turpmāk - LU) Bibliotēka organizēja zinātnisko konferenci "LU Rakstu nozīmība: nenovērtēta vai pārvērtēta”, kas bija veltīta LU 96. gadadienai un kas rosināja pievērsties docētāju kā augstākās izglìtības pedagogu profesionālās pilnveides pieredzes izpētei LU Rakstos.

Docētāja darbā Universitātē nozīmīga darba daḷa ir zinātniski pētnieciskais darbs un to rezultātu publicēšana, tomēr ne augstākās izglītības iestādes institucionālā, ne docētāja individuālā līmenī nevajadzētu aizmirst arī par akadēmiskā personāla pilnveides nozīmi pedagogiskās darbības jomā, jo studiju darbs ir būtiska ikviena docētāja profesionālās darbības daḷa.

\section{Pētijuma metodoloǵijas raksturojums}

Izpētes procesā tika izmantoti gan drukātie, gan elektroniskajā versijā esošie LU Rakstu sējumi LU e-resursu repozitorijā.

Sākotnēji tika iegūts priekšstats par LU Rakstu krājumu apjomu. "Latvijas Augstskolas Rakstos" (izdoti no 1921. līdz 1923. gadam, katrā sējumā ietverot dažāda satura rakstus bez tematiskās atlases) pirmā publikācija, kas pieskaras docētāju profesionālās pilnveides jautājumiem, ir 1922. gada 4. sējumā publicētais k̦īmiķa LU profesora Karla Blahera (Carl Johann Blacher, 1867-1939) raksts Die pädagogische Systematisierung der feuerungstechnischen Einrichtungen (Blacher, 1922). Vairākas Karla Blahera publikācijas apliecina, ka viņš rūpējies par studiju procesa pedagoǵiskajiem jautājumiem. Kā norāda pedagogijias vēstures pētniece Alīda Zigmunde: "Viņš allaž domāja par to, kā labāk mācīt un iemācīt, tāpēc ārzemju komandējumos centās iepazīties ar citu augstskolu mācībspēku pieredzi augstskolas un ķīmijas didaktikā, domāja 
par laboratorijas prakses piemērošanu siltumtehnikas studijām. İpaši vinnu interesēja, kā uzlabot darbu ar k̦īmijas tehnologijas studentiem." (Zigmunde, 2010, 12) K. Blahers ir pievērsis ìpašu uzmanību teorijas un prakses sasaistei: "Pievēršot uzmanību studentu sagatavošanai un prakse, K. Blahers domāja ne tikai par augstskolas didaktiku lekcijās, bet arī par dažādām ekskursijām uz dažādām rūpnīcām un fabrikām." (Zigmunde, 2010, 13)

Dažādās zinātṇu nozarēs arī mūsdienās darbojas docētāji, kas veic pētījumus ne tikai savā nozarē, bet arī augstskolas pedagogijijā un publicē tos savu nozaru LU Rakstu krājumos. Piemēram, docētājas un pētnieces psiholog̣ijas nozarē Sarmìte Voitkāne un Solveiga Miezìte LU Rakstu "Psiholoǵijas" sērijā (768. sēj.) publicējušas rakstu "Latvijas Universitātes 2006./2007. gada 1. kursa studentu adaptācijas problēmas pirmā studiju gada sākumā" (Voitkāne, Miezìte, 2011). Savukārt pēc starptautiskā 8. IOSTE (The International Organization for Science and Technology Education) Centrāleiropas un Austrumeiropas simpozija "Dabaszinātņu un tehnologiju izglitīiba: attīstības tendences un virzieni 21. gadsimtā" LU Rakstu sērijā "Ķīmija. Dabaszinātņu izglìitiba" (2011, 778. sēj.) arī atrodami raksti par dabaszinātņu saturu un mācỉbu metodiku augstākajā izglìtībā.

LU Rakstu sērijā "Ekonomika un vadības zinātne" ir publikācijas par izglitīibas sistēmas politiskajiem, ekonomiskajiem aspektiem un augstākās izglītỉbas kvalitātes nodrošināšanu. Savukārt LU Rakstu sērijā "Zinātṇu vēsture un muzejniecība" ievietotas publikācijas par atsevišķām personībām un to devumu kādas nozares attīstībā, t. sk. docēšanā. Piemēram, LU Rakstu 800. sējumā (2014) lasāmi raksti par personībām, zinātṇu nozaru (biologijas, pedagoǵijas, medicīnas u. c.) vēsturisko attīstību LU. Publikācijās raksturota LU struktūrvienību un apakšstruktūrvienību attīstība, nosaukti to vadìtāji, raksturoti studiju kursi, aktuālie pētniecības virzieni, analizēta docētāju akadēmiskā darba pieredze atbilstīgo vēsturisko, politisko apstākḷu kontekstā, izmantojot gan dokumentālās, gan laikabiedru liecības, u. tml. Pieminēts arī, kādos profesoru pètijumos iesaistìti studenti un paši profesori, kas veicinājuši studentu pētniecisko darbu, un kā profesori ietekmējuši studenta turpmākās profesionālās un pētnieciskās intereses. Līdzịgi arī LU 80. un 85. gadu jubilejai veltìtajos LU Rakstu krājumos ir vairāki raksti par Universitātes institucionālo attīstību, studiju procesa pilnveidi.

Laikā no 2000. līdz 2015. gadam izdots bagāts LU Rakstu sējumu klāsts pedagoǵijas zinātnē un izglitības zinātṇu nozarēs - vismaz viens sējums katru gadu, iznemot 2003., 2005., 2011. gadu (1. att.). Rakstos apkopota Latvijas, Lietuvas, Turcijas un Ukrainas pētnieku pieredze augstākās izglìtības un augstskolas pedagogiijas jomā. 


\begin{tabular}{|c|c|c|c|c|c|}
\hline \multicolumn{6}{|c|}{ LU Raksti (2000-2015) } \\
\hline $\begin{array}{c}\text { Rakstu sērijas } \\
\text { nosaukums }\end{array}$ & $\begin{array}{c}\text { Izglìtības } \\
\text { kvalitäte } \\
\text { un vadība }\end{array}$ & $\begin{array}{c}\text { Izglitīibas } \\
\text { zinātnes un } \\
\text { pedagogìija } \\
\text { mūsdienu } \\
\text { pasaulē }\end{array}$ & Pedagoǵija & $\begin{array}{l}\text { Pedagoǵija } \\
\text { un } \\
\text { skolotāju } \\
\text { izglìtība }\end{array}$ & $\begin{array}{l}\text { Izglìtības } \\
\text { vadība }\end{array}$ \\
\hline Krājumi & 1 & 3 & 4 & 8 & 6 \\
\hline $\begin{array}{l}\text { Publikācijas par aug- } \\
\text { stāko izglītību un } \\
\text { augstskolas pedagogiju }\end{array}$ & 2 & 38 & 20 & 31 & 32 \\
\hline
\end{tabular}

1. attēls. LU Rakstu krājumu un publikāciju par augstāko izglītību un augstskolas pedagogiiju kopskaits (2000-2015)

Tika atlasītas šādas LU Rakstu sērijas, kurās visvairāk atrodami raksti par augstāko izglītību un augstskolas pedagogiju: "Izglìtības kvalitāte un vadība", "Izglītỉbas zinātnes un pedagogija mūsdienu pasaulē", "Pedagogija”, "Pedagoǵija un skolotāju izglītība", "Izglīî̉bas vadība”. Aplūkojot Rakstu sēriju dažādību un dinamiku (2. att.), uzskatāmi atklājas, kādas problēmas, kas saistās ar izglìtību un pedagogiju, tika pētītas un risinātas augstskolas docētāju darbā dažādos laika posmos.

\begin{tabular}{|c|c|c|c|c|c|c|c|c|c|c|c|c|c|c|c|c|}
\hline $\begin{array}{l}\text { LU Rakstu } \\
\text { sērijas nosaukums }\end{array}$ & ஜ் & $\dot{\vec{\delta}}$ & ญ̊̀ & हి் & ठ্ণ & ஜั่ & ठั & ¿̊̊̆ & 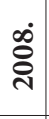 & ठิે & 官 & $\dot{\vec{n}}$ & ì & $\stackrel{\dot{m}}{\stackrel{\sim}{े}}$ & ت্ & \\
\hline & 1 & 0 & 0 & 0 & 0 & 0 & 0 & 0 & 0 & 0 & 0 & 0 & 0 & 0 & 0 & 0 \\
\hline $\begin{array}{l}\text { Izglìtības zin } \\
\text { pedagoǵija } m \\
\text { pasaulēe }\end{array}$ & 0 & 1 & 2 & 0 & 0 & 0 & 0 & 0 & 0 & 0 & 0 & 0 & 0 & 0 & 0 & 0 \\
\hline Pedagogiija & 0 & 1 & 0 & 0 & 2 & 0 & 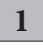 & 0 & 0 & 0 & 0 & 0 & 0 & 0 & 0 & 0 \\
\hline $\begin{array}{l}\text { Pedagoóija u } \\
\text { izglitìiba }\end{array}$ & 0 & 0 & 0 & 0 & 0 & 0 & 0 & 1 & 1 & 1 & 1 & 0 & 1 & 1 & 2 & 0 \\
\hline Izglìtības vadìba & 0 & 0 & 0 & 0 & - & 0 & 2 & 0 & 0 & 1 & 0 & 0 & 0 & 1 & 0 & 1 \\
\hline Kopā (22) & 1 & 2 & 2 & 0 & 3 & 0 & 3 & 1 & 1 & 2 & 1 & 0 & 1 & 2 & 2 & 1 \\
\hline
\end{tabular}

2. attēls. Augstākajai izglītībai un augstskolas pedagogijai veltītas publikācijas LU Rakstos (2000-2015)

Rakstā padziļināti analizētās LU Rakstu sērijas izdotas no 2000. līdz 2015. gadam. Vispirms satura analīzei tika izvēlēti raksti par augstskolas pedagog̣iju un augstāko izglītību, bet padziḷinātai satura analīzei - raksti, kuros bija atspoguḷota docētāju profesionālās pilnveides pieredze.

Universitātes docētājiem nepieciešams izstrādāt zinātniskās publikācijas. Par izpētes priekšmetu kḷūst arī pašu docētāju pedagogiskais darbs. 


\section{Docētāju profesionālā pilnveide}

Profesionālā pilnveide ir dinamiska mācīšanās profesionālās attīstības gaitā, lai uzlabotu indivīda profesionālo darbību, kuru ietekmē gan ārēji, gan iekšêji faktori. Profesionālā pilnveide ir process, kura laikā cilvēks iegūst zināšanas, izpratni, vēlmi/gribu kaut ko mainìt, vēlmi pēc pārmaiṇām savā profesionālajā darbībā (Baranova, 2012).

Profesionālās pilnveides rezultāts ir priekšnoteikums kvalitatīvām izmaiñām profesionālajā darbībā, bet negarantē tās. Tikai līdz ar darīšanu un reālu pārmaiņu veikšanu notiek profesionālās darbības pilnveide. Profesionālās darbības pilnveide ir profesionālās attīstības nākamais posms: ir svarīgi, lai tas, kas ir iemācīts, patiešām tiktu izmantots/īstenots darbībā.

Pieredzes apmaiņa ir došanas un ņemšanas darbïbas, kurās personas savstarpēji bagātina cita citu ar savā darbībā iegūtajām zināšanām un prasmēm. Docētāja darbā tā ir augstākā profesionalitātes attīstības pakāpe, kad docētājs var savu pieredzi nodot citiem. Pieredzes apzināšana un refleksija nodrošina iespēju pārvērst pieredzi par zināšanām un nodot to citiem.

LU Pedagoǵijas un psihologijas fakultāte (tagad - LU Pedagoǵijas, psihologijas un mākslas fakultāte) un Izglìības pētniecības institūts 2000. gadā izdevis LU Rakstu krājumu sērijā "Izglīīibas kvalitāte un vadība" (626. sēj.). Krājumā iekḷauti raksti par izglìtibas kvalitātes izpratni un uzlabošanas aktualitāti un pētijjumiem dažādās izglîtības pakāpēs un institūcijās, salīdzinoši izvērtējot ārzemju pieredzi izglìtībā. No tiem par pētijuma tematam atbilstīgiem tika atzìti divi raksti. Vienā no tiem autori - LU un Latvijas Lauksaimniecības universitātes docētāji Andris Kangro un Ilze Kazaine - izvērtē situāciju moderno informācijas tehnolog̣iju ieviešanā Latvijas augstskolās un raksturo tās (Kangro, Kazaine, 2000), otrajā rakstā Rēzeknes Augstskolas docētāja Zaiga Matule analizē augstākās izglìtības regionālos aspektus un to saistību ar ekonomiskajām un sociālajām pārmaiņām valstī (Matule, 2000).

LU Pedagoǵijas un psihologiijas institūts 2001. gadā zinātnisko rakstu krājumu sērijā "Latvijas Universitātes Raksti / Acta Universitatis Latviensis" izdevis rakstu krājumu "Pedagogija" (641. sēj.). Tas ir vienīgais sējums, kas nav izdots LU Akadēmiskajā apgādā un izpētes veikšanas laikā nebija pieejams elektroniski LU e-resursu repozitorijā. No šì sējuma tika atlasìti četri raksti: Jamala Abu-Hussaina raksts "Profesionālā socializācija pedagog̣iskajos institūtos arābu izglìīibas sistēmā Izraēlā" (Abu-Hussains, 2001), Sarmas Cakulas - "Informācijas tehnologiijas pētnieciskajā darbībā augstskolā kā studiju produktivitātes pilnveidošanas lïdzeklis" (Cakula, 2001), Montas Farnestes - "Rakstveida saziņas apguves problēmas augstskolā" (Farneste, 2001) un Ilzes Strepmanes - "Studentu pašvērtējums studiju procesā” (Strepmane, 2001). Visu rakstu autori publikācijas izstrādes brīdī studēja doktora studiju 
programmā "Pedagog̣ija", un publikācijā atspoguḷota disertācijas pētijuma gaita un rezultāti. Šajā kontekstā jāatzīmē specifika, ka daudzi pedagog̣ijas doktoranti un izglitīibas vadības doktoranti ir augstskolu docētāji, kuru pètījumi ir saistīti ar augstākās izglīîibas jomu vai augstskolas pedagoǵiju.

LU Rakstu sērijā "Izglīîibas zinātnes un pedagog̣ija mūsdienu pasaulē" ir publicēti trīs sējumi (635., 649. un 655. (656.) sēj.). 635. sējumā (2001) ir publicēti 22 raksti, 649. sējumā (2002) - deviṇi raksti, kā arī 655. (656.) sējumā (2002) - devinini raksti par augstkolas pedagogijas un augstākās izglìîibas jautājumiem. Savukārt 2004. gadā sērijā "Pedagog̣ija" izdoti divi sējumi (670. un 678. sēj.), kuros kopā lasāmi 15 raksti gan par augstskolas pedagog̣iju, gan par augstāko izglìitibu. Kopš 2007. gada tiek izdota LU Rakstu sērija "Pedagogiija un skolotāju izglìtỉba" (3. att.).

\begin{tabular}{|c|c|c|c|c|c|c|c|}
\hline & \begin{tabular}{|c|}
$\begin{array}{c}\text { LU Rakstu sērijas } \\
\text { nosaukums }\end{array}$ \\
\end{tabular} & $\begin{array}{l}\text { Sējuma } \\
\text { numurs }\end{array}$ & $\begin{array}{c}\text { Izdošanas } \\
\text { gads }\end{array}$ & & \begin{tabular}{|c|}
$\begin{array}{c}\text { LU Rakstu sērijas } \\
\text { nosaukums }\end{array}$ \\
\end{tabular} & $\begin{array}{l}\text { Sējuma } \\
\text { numurs }\end{array}$ & $\begin{array}{c}\text { Izdošanas } \\
\text { gads }\end{array}$ \\
\hline 1. & $\begin{array}{l}\text { Izglìtības kvalitāte } \\
\text { un vadība }\end{array}$ & 626. & 2000 & 12. & $\begin{array}{l}\text { Pedagoǵija un } \\
\text { skolotāju izglìtība }\end{array}$ & 715. & 2007 \\
\hline 2. & $\begin{array}{l}\text { Izglìtības zinātnes } \\
\text { un pedagoǵija } \\
\text { mūsdienu pasaulē }\end{array}$ & 635. & 2001 & 13. & $\begin{array}{l}\text { Pedagogija un } \\
\text { skolotāju izglītība }\end{array}$ & 741. & 2008 \\
\hline 3. & Pedagogiija & 641. & 2001 & 14. & $\begin{array}{l}\text { Pedagoǵija un } \\
\text { skolotāju izglìtība }\end{array}$ & 747. & 2009 \\
\hline 4. & $\begin{array}{l}\text { Izglìtības zinātnes } \\
\text { un pedagoğija } \\
\text { mūsdienu pasaulē }\end{array}$ & 649. & 2002 & 15. & Izglìtības vadība & 749. & 2009 \\
\hline 5. & $\begin{array}{l}\text { Izglìtības zinātnes } \\
\text { un pedagog̀ija } \\
\text { mūsdienu pasaulē }\end{array}$ & $\begin{array}{l}655 . \\
(656)\end{array}$ & 2002 & 16. & $\begin{array}{l}\text { Pedagogija un } \\
\text { skolotāju izglītība }\end{array}$ & 759. & 2010 \\
\hline 6. & Pedagogíija & 670. & 2004 & 17. & $\begin{array}{l}\text { Pedagoǵija un } \\
\text { skolotāju izglìtība }\end{array}$ & 781. & 2012 \\
\hline 7. & Izglìtìbas vadība & 675. & 2004 & 18. & $\begin{array}{l}\text { Pedagogija un } \\
\text { skolotāju izglìtība }\end{array}$ & 790. & 2013 \\
\hline 8. & Pedagogíija & 678. & 2004 & 19. & Izglìtības vadība & 792. & 2013 \\
\hline 9. & Izglìtìbas vadība & 697. & 2006 & 20. & $\begin{array}{l}\text { Pedagoóija un } \\
\text { skolotāju izglìtība }\end{array}$ & 795. & 2014 \\
\hline 10. & Pedagogiija & 700. & 2006 & 21. & $\begin{array}{l}\text { Pedagogiija un } \\
\text { skolotāju izglìtība }\end{array}$ & 802. & 2014 \\
\hline 11. & Izglitīibas vadība & 709. & 2006 & 22. & Izglìtības vadība & 807. & 2015 \\
\hline
\end{tabular}

3. attēls. LU Rakstu sērijas augstākajā izglītībā un augstskolas pedagoǵijā (2000-2015)

2012. gadā LU 70. konferences pedagoǵijas zinātnes plenārsēde un sekcijas sēde tika veltîtas tieši docētāju tālākizglìtībai. 2013. gadā izdotajā sērijā 
"Pedagoǵija un skolotāju izglīîiba" (690. sēj.) raksti publicēti trīs tematiskajos blokos:

1. Augstskolu docētāju profesionālā pilnveide: saturs un organizācija.

2. Augstskolu docētāju profesionālā kompetence: raksturojums un izvērtēěana.

3. Skolotāju tālākizglìtība un profesionālā pilnveide: pieredze un izaicinājumi.

Savukārt 2014. gadā sērijā "Pedagogija un skolotāju izglîtîba" ir divi raksti par augstākās izglìtîbas studiju programmu attīstību. LU prof. Rasmas Garlejas un Airitas Brenčas publikācija "Izglìtības vadības un pedagoǵijas zinātnes mijattiecības" veltìta augstākās izglìtības organizācijas funkciju izpētei akadēmiskajā menedžmentā, uzsverot zinātniskās pedagoǵijas priekšmeta arvien plašāku lietojumu, pētot mūsdienu pedagogijas paradigmas un sociokultūras attīstîbas tendences (Garleja, Brenča, 2014). Otra raksta autors - Ukrainas Nacionālās Dragomanova pedagogiiskās universitātes docētājs Genadijs Stavitskis (Gennadiy Stavitskiy) - savā rakstā Psychological Analysis of Motivation for Studying at the Pedagogical University among Students of Different Specialties (Psihologiskā analīze dažādu specialitāšu studentu motivācijai studēt pedagogisiskajā universitātē) analizē pirmā kursa studentu profesionālās darbības jomas izvēles motivāciju un pèta studentu profesionālās pašnoteikšanās dinamiku (Stavitskiy, 2014).

Tajā pašā 2014. gadā klajā nāca vēl viens LU Rakstu krājums sērijā "Pedagog̣ija un skolotāju izglîtība" (802. sēj.), kas papildināja tēmu par augstākās izglìtības studiju programmu attīstību ar trim rakstiem. Sandra Kalniņa rakstā "Otrā līmeṇa profesionālās augstākās izglìīibas studiju programmas "Skolotājs" ìstenošanas pieredze Latvijas Universitātē" analizē studiju programmas īstenošanas pieredzi (programma izstrādāta Eiropas Sociālā fonda projekta "Inovatīva un praksē balstìta pedagogu izglïîibas ieguve un mentoru profesionālā pilnveide" ietvaros) (Kalniņa, 2014). Rakstā tiek norādīts uz programmas izstrādes saistību ar pieprasījumu un skolotāju profesionālajām vajadzībām, kā arī analizētas studējošo aptaujas par personības un profesionālajiem ieguvumiem studijās. Raksta "Eiropas logopēdijas pamatizglítības standarts - izaicinājums Latvijas logopēdijai" autores Baiba Trinīte un Sarmìte Tūbele analizē Eiropas logopēdijas studiju programmu harmonizācijas NetQues projektu un raksturo tā īstenošanas galveno rezultātu (Trinīte, Tūbele, 2014). Savukārt kolēge no Lietuvas Lilija Žukauskiene (Lilia Žukauskienè) publikācijā "Skolotāju sagatavošana Lietuvā padomju periodā: refleksija par pieredzi" (Teacher Training in Lithuania during the Soviet Period: Reflection on the Experience) raksturojusi skolotāju izglìtibu Lietuvā padomju varas periodā un, balstoties uz skolotāju interviju par padomju laikā iegūto izglìtības 
pieredzi, analizējusi, kāda ir vēsturisko notikumu ietekme uz skolotāju izglītîbu mūsdienās (Žukauskienè, 2014).

LU Rakstu 807. sējumā, kas tika izdots 2015. gadā (sērija "Izglìīibas vadỉba”), par augstāko izglitīibu publicēti divi raksti. Abu rakstu autores ir no Turcijas, viņas tajā laikā bija LU Pedagog̣ijas, psihologijas un mākslas fakultātes izglīīibas vadības doktora studiju programmas doktorantes. Abi raksti ir angḷu valodā ar kopsavilkumu latviešu valodā. Vienā rakstā - Development of Lifelong Learning in Turkey (Mūžizglìtỉbas attīstība Turcijā) (Basak, 2015) raksturota mūžizglīîibas attīstîba Turcijā, tās organizācija Turcijas universitātēs, kas vēl bez ārpus formālās izglìtỉbas sistēmas programmu īstenošanas piedāvā arī daudzveidīgas tālākizglîtības iespējas plašam interesentu lokam. Savukārt otrajā rakstā - Mobility as a Way to Internationalisation (Mobilitāte kā cẹ̦š uz internacionalizāciju) (Burcer, 2015) - salīdzinoši analizēta starptautiskā studentu mobilitāte Turcijā un Latvijā, ņemot vērā valstu ekonomiskās attīstības rādītājus.

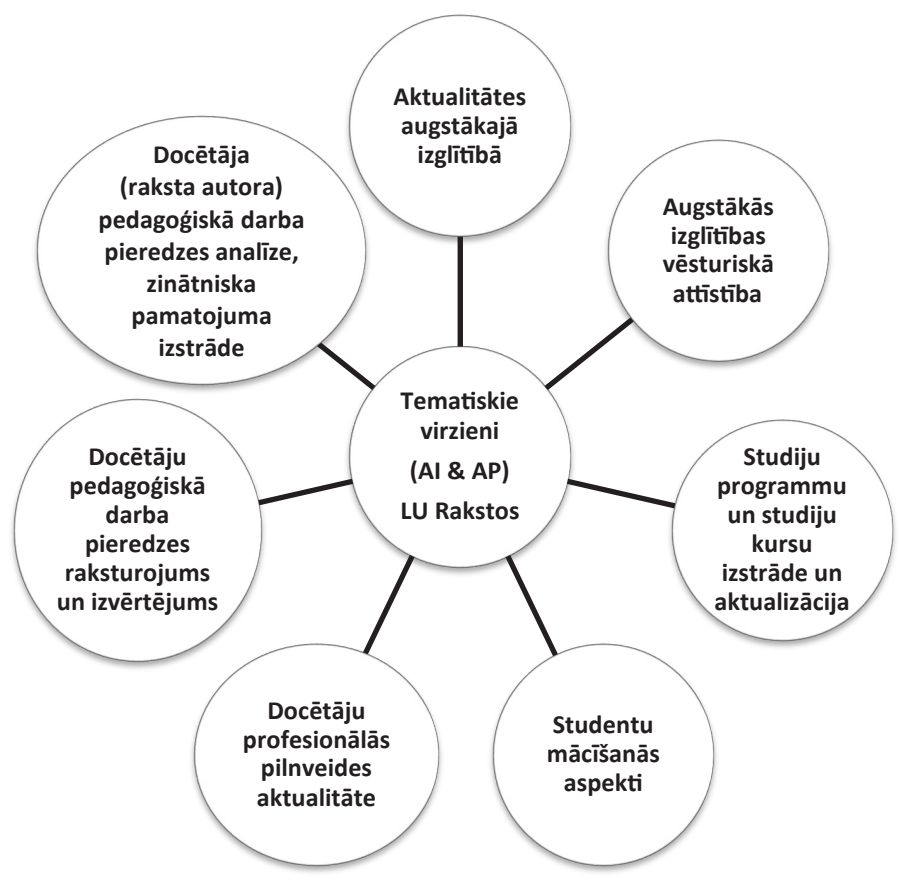

4. attēls. LU Rakstos atspoguḷotie tematiskie virzieni augstākajā izglītībā un augstskolas pedagogijā

Apkopojot padziḷinātai satura analīzei atlasīto LU Rakstu saturu, iespējams izšķirt vairākus tematiskos virzienus augstākajā izglitīiā un augstskolas 
pedagogijāa: aktualitātes augstākajā izglìtībā; augstākās izglìtības vēsturiskā attīstība; studiju programmu un studiju kursu izstrāde un aktualizācija; studentu mācišanās aspekti; docētāju profesionālās pilnveides aktualitāte; docētāju pedagoǵiskā darba pieredzes raksturojums un izvērtējums; docētāja pedagogiskā darba pieredzes analīze, zinātniska pamatojuma izstrāde (4. att.).

\section{Secinājumi}

1. LU Rakstos atspoguḷotā docētāju profesionālās pilnveides pieredze raksturo docētāju zinātnisko un pedagoǵisko devumu, kā arī pētniecisko pieeju pedagoǵiskajai darbībai augstskolā.

2. LU Raksti ir akadēmiskā personāla pieredzes un laikmeta liecỉba. Tie ir noderīgs mācišanās un izziņas avots gan šo publikāciju autoru kolêgiem, gan studentiem un citiem nozares speciālistiem.

3. Rakstu autoru uzmanības centrā ir plašs augstākās izglìtības un pedagogijas pētijumu lauks: studiju process un tā dalībnieki, augstākās izglìtības reǵionālie aspekti valstī, augstākās izglìtības studiju programmu pilnveide, mūžizglìīibas attīstība un citas tēmas.

4. Ikgadējās LU starptautiskās zinātniskās konferences un LU Raksti ir doktorantu un jauno docētāju pētījumu rezultātu popularizēšanas iespēja, kas sniedz izdevību diskutēt par pētijumu problēmaspektiem, pilnveidojot un bagātinot savu zinātnisko pieredzi.

5. LU Rakstos uzskatāmi redzama docētāju akadēmiskās karjeras attīstîba no publikācijām maǵistranta vai doktoranta statusā līdz publikācijām docenta, asociētā profesora vai profesora akadēmiskajā amatā.

6. LU Rakstus būtu nepieciešams iekḷaut zinātniskās citējamības un citās nozīmīgās datubāzēs, kas būtu nevis katras nozares atsevišşss uzdevums, bet visas augstskolas kopdarbs.

\section{IZMANTOTIE INFORMĀCIJAS AVOTI}

1. Abu-Hussains J. (2001). Profesionālā socializācija pedagogískajos institūtos arābu izglìtibas sistēmā Izraēlā. No: LU Raksti. 641. sēj. Rīga: LU PPI, 25.-37. lpp.

2. Baranova S. (2012). Augstskolu docētāju profesionālā pilnveide tālākizglìtībā. Promocijas darbs. Rīga: LU.

3. Başak E. (2015). Development of Lifelong Learning in Turkey. No: LU Raksti. 807. sēj. Rīga: LU, 40.-49. lpp.

4. Blacher C. (1922). Die pädagogische Systematisierung der feuerungstechnischen Einrichtungen. No: Latvijas Augstskolas Raksti. 4. sēj. Rìga: Latvijas Augstskola, 223. -233 . lpp. 
5. Burçer S. (2015). Mobility as a Way to Internationalisation. No: LU Raksti. 807. sēj. Rìga: LU, 40.-49. lpp.

6. Cakula S. (2001). Informācijs tehnolog̣ijas pētnieciskajā darbībā augstskolā kā studiju produktivitātes pilnveidošanas līdzeklis. No: LU Raksti. 641. sēj. Rīga: LU PPI, 81.-96. lpp.

7. Farneste M. (2001). Rakstveida saziṇas apguves problēmas augstskolā. No: LU Raksti. 641. sēj. Rīga: LU PPI, 97.-104. lpp.

8. Garleja R., Brenča A. (2014). Izglīiības vadības un pedagogijas zinātnes mijattiecības. No: LU Raksti. 795. sēj. Rīga: LU, 40.-45. lpp.

9. Kangro A., Kazaine I. (2000). Informātiskā izglīīiba LLU un citās Latvijas augstskolās. No: LU Raksti. 626. sēj. Rīga: LU, 100.-115. lpp.

10. Kalniņa S. (2014). Otrā līmeņa profesionālās augstākās izglìtības studiju programmas "Skolotājs" īstenošanas pieredze Latvijas Universitātē. No: LU Raksti. 802. sēj. Rìga: LU, 73.-80. lpp.

11. Ķīmija. Dabaszinātņu izglìtība: Starptautiskais 8. IOSTE Centrāleiropas un Austrumeiropas simpozijs "Dabaszinātņu un tehnologiju izglītiba: attīstības tendences un virzieni 21. gadsimtā": 30. novembris - 3. decembris, 2011, Rīga, Latvija. No: LU Raksti. 778. sēj. Rīga: LU, 269 lpp.

12. Matule Z. (2000). Galvenās iezīmes Latgales lauku rajonu jauniešu augstākās izglītỉbas gaitās 1997.-1998. gadā. No: LU Raksti. 626. sēj. Rīga: LU, 143.-153. lpp.

13. Stavitskiy G. (2014). Psychological analysis of motivation for studying at the pedagogical university among students of different specialties. No: LU Raksti. 795. sēj. Rīga: LU, 85.-93. lpp.

14. Strepmane I. (2001). Studentu pašvērtējums studiju procesā. No: LU Raksti. 641. sēj. Rìga: LU PPI, 274.-286. lpp.

15. Trinīte B., Tūbele S. (2014). Eiropas logopēdijas pamatizglìtíbas standarts izaicinājums Latvijas logopēdijai. No: LU Raksti. 802. sēj. Rīga: LU, 156.-166. lpp.

16. Voitkāne S., Miezīte S. (2011). Latvijas Universitātes 2006./2007. gada 1. kursa studentu adaptācijas problēmas pirmā studiju gada sākumā. No: LU Raksti. 768. sēj. Rīga: LU, 225.-245. lpp.

17. Zigmunde A. (2008). Pedagogiskā darbība Rīgas politehnikumā un Rīgas Politehniskajā institūtā (1862-1919). Rīga: RaKa.

18. Zigmunde A. (2010). Profesora Karla Blahera daudzpusīgā darbība. In: Scientific Journal of Riga Technical University. The Humanities and Social Science. History of Science and Higher Education, 6, 12.-16. lpp.

19. Žukauskiené L. (2014). Skolotāju sagatavošana Lietuvā padomju periodā: refleksija par pieredzi. No: LU Raksti. 802. sēj. Rīga: LU, 204.-217. lpp. 